\title{
NCOA4/RET Fusion Protein
}

National Cancer Institute

\section{Source}

National Cancer Institute. NCOA4/RET Fusion Protein. NCI Thesaurus. Code C99848.

A fusion protein encoded by the NCOA4/RET fusion gene. This protein is comprised of approximately $240 \mathrm{~N}$-terminal amino acids of the nuclear receptor coactivator 4 protein, fused with most of the C-terminal cytoplasmic domain of the proto-oncogene tyrosineprotein kinase receptor Ret protein, including the tyrosine kinase domain. 